\title{
No regaço da mãe Faustina: uma ama escrava e a educação da criança pela família no século $\mathrm{XIX}^{1}$
}

\section{In the lap of mother Faustina: a slave nurse and the education of children by the families in the $19^{\text {th }}$ century}

\author{
Juarez José Tuchinski dos Anjos²
}

\begin{abstract}
RESUMO
O objetivo do artigo é identificar as práticas educativas engendradas pelas amas escravas no interior da família e como elas podem ter se tornado práticas de educação das crianças sob seus cuidados. $\mathrm{O}$ estudo recai sobre a cidade de Paranaguá, Província do Paraná, na década de 1870. As fontes documentais são constituídas por relatos escritos por membros da família Correia, que preservou, na memória familiar, evidências da educação dada pela ama Faustina ao pequeno Leocádio Cysneiros Correia, nascido em 1876. Na primeira parte do artigo são interpretados alguns vestígios da trajetória da escrava Faustina no interior da família Correia, enquanto que na segunda parte são analisadas as práticas educativas de que ela e outras amas escravas parecem ter lançado mão na educação da criança, no interior da família, no século XIX.
\end{abstract}

Palavras-chave: amas escravas; educação; família; Paraná; século XIX.

\footnotetext{
ABSTRACT

This paper aims at identifying the educational practices engendered by slave nurses within the families and how such practices may have become educational practices of children under their care. The study covered the

DOI: $10.1590 / 0104-4060.44007$

1 Pesquisa financiada pela Comissão de Aperfeiçoamento de Pessoal de Nível Superior

2 Universidade Federal do Paraná. Curitiba, Paraná, Brasil. Rua General Carneiro, $n^{\circ} 460$. CEP: 80060-150.E-mail: juarezdosanjos@yahoo.com.br
} (CAPES). 
decade of 1870 in the city of Paranaguá, Province of Paraná. Documentary sources consisted of reports written by members of the Correia family, which preserved in the family memories evidences of the education given by the nurse Faustina to little Leocádio Cysneiros Correia, who was born in 1876. The first part of the paper presents interpretations of some traces of the life of the slave Faustina within the Correia family; the second part presents analyses of the educational practices that she and other slave nurses seemingly used in the education of children within the families in the $19^{\text {th }}$ century.

Keywords: slave nurses; education; family; Paraná; $19^{\text {th }}$ century.

Recentemente, concluí uma pesquisa que tomou por objeto de estudo as práticas de educação da criança pela família, na Província do Paraná. (ANJOS, 2015). Minha atenção recaiu sobre a atuação dos pais e mães na educação de seus filhos. Contudo, ao longo da investigação histórica, deparei-me com aquilo que Maria Celi Vasconcelos (2005) já havia constatado no Rio de Janeiro Oitocentista: a existência de outros atores que, dentro da família, em alguns momentos ou fases da infância, também participavam da educação dos pequenos. Em particular, despertou meu interesse a presença das denominadas "mães pretas", isto é, amas de leite e/ou amas-secas escravas, que, apesar dos preconceitos raciais e sociais existentes - que desqualificavam a mulher negra e cativa como educadora -, exerciam determinadas formas de educação da criança na família.

A figura da ama é uma das facetas femininas mais conhecidas na história da infância e das mulheres no Brasil. Enfocada nos estudos na sua função de nutriz, pouca atenção tem sido dada ao seu papel educativo na vida dos infantes, para além da dimensão biológica da alimentação e criação. No Brasil Oitocentista, não foram raras as escravas que, adentrando numa família como amas de leite, para nutrir o Nhonhô ou a Sinhazinha, após o período de lactação, ali permaneceram como amas-secas, incorporando essa identidade de "mãe preta", coadjutora da mãe livre na educação dos filhos desta durante a infância, conforme destacou Sandra Graham (1992) no seu famoso estudo sobre as criadas no Rio de Janeiro.

Mas, é possível considerar a ama escrava uma educadora sem cometer um anacronismo? Afinal, a historiografia que tem estudado essas mulheres no Brasil Império vai lembrar-nos que era justamente o contrário que delas pensavam os médicos e a imprensa periódica. Antes, era a sua suposta inaptidão para educar a marca mais característica do discurso de que foram alvos ao longo do XIX, como evidenciaram, dentre outras, Maria Vittória Civiletti (1991) e Karoline Karula (2012). Contraditoriamente, o que esses discursos e seus enunciadores pareciam não ignorar era o fato de que entre as amas e as crianças sob seus cuidados existia sim uma relação educativa, que, no entanto, queriam dar paradeiro ou modificar. 
Realmente, embora a ação educativa das amas ainda não tenha sido objeto específico de estudo, tangencialmente, a historiografia tem apontado fortes indícios da existência desse fenômeno educativo pretérito, ainda que permeado por essa contradição. Sandra Graham, por exemplo, não deixou de notar que "[...] as amas de leite, com reconhecida influência sobre as crianças, podiam ameaçar-lhes o bem estar tanto moral quanto físico [e que] por isso "nenhum mau hábito congênito ou adquirido' podia ser permitido”'(GRAHAM, 1992, p. 138), sugerindo que, pelo fato de serem capazes de incutir comportamentos e condutas, é que se exigia delas que tivessem bons hábitos, a fim de não tornarem-se maus exemplos para os que deveriam nutrir e cuidar. Geórgia Quintas, analisando a Província de Pernambuco, embora se detendo mais nos aspectos de sociabilidade estabelecidos entre as amas e as famílias que as acolhiam, afirma que o papel da ama de leite incluía "[...] o cuidado direto com as crianças e os importantes primeiros contatos com a educação delas". (QUINTAS, 2009, p. 14). Maria Celi Vasconcelos, desbravando o interior dos lares para estudar a instrução elementar dada na Casa, não deixou de perceber que a presença das amas era, em certa medida, fonte de outros tipos de educação também ali ministrados. A força delas e dessa possível educação na vida das crianças era tamanha que, muitas vezes, tais mulheres representavam forte oposição à instrução das primeiras letras dada por preceptores no interior das residências das famílias abastadas, coisa que era denunciada pela imprensa fluminense. (VASCONCELOS, 2005).

Entretanto, foi Gilberto Freyre quem, com maior expansividade, observou e relatou as formas pelas quais as amas de leite cativas tornaram-se educadoras da infância brasileira, desde o período colonial. Em Casa Grande \& Senzala, inicia o primeiro dos dois capítulos sobre "o escravo negro na vida sexual e de família do brasileiro" falando da presença e lugar da ama nesse processo:

\begin{abstract}
Na ternura, na mímica excessiva, no catolicismo em que se deliciam nossos sentidos, na música, no andar, na fala, no canto de ninar do menino pequeno, em tudo que é expressão sincera de vida, trazemos quase todos a marca da influência negra. Da escrava ou sinhama que nos embalou. Que nos deu de mamar. Que nos deu de comer, ela própria amolengando na mão o bolão de comida. Da negra velha que contou as primeiras histórias de bicho e de mal assombrado [...]. (FREYRE, 2000, p. 343).
\end{abstract}

Ainda que neste primeiro trecho o sociólogo sugira que a ama se limitava às tarefas de nutriz e pajem e que era a "negra velha" quem contava estórias em certa medida educativas, mais adiante, Freyre esclarece serem as amas as que 
por primeiro as narravam aos pequenos, aventando, para os fins de uma história da educação - que ele anuncia, mas não chega a escrever -, ter sido por meio de cantigas, estórias e do próprio ensino das primeiras palavras - ainda que de um português "inculto" - que a ama escrava deu-lhes uma primeira educação.

A partir desse diálogo inicial com a historiografia brasileira recente e, sobretudo, a freyreana, é que elegi como objeto de estudo neste artigo as práticas empregadas pela "mãe preta" na educação da criança na família, tanto na condição de ama de leite como de ama-seca. Entendendo a educação como a transmissão de hábitos, comportamentos e condutas à criança no tempo da infância com vistas ao adulto que se espera que ela venha a ser (ANJOS, 2015), o objetivo aqui é identificar as práticas educativas engendradas pela "Mãe Preta" e como elas podem ter se tornado práticas de educação das crianças sob seus cuidados.

Gilberto Freyre (2000), ao relatar que canções lusitanas entoadas pelas amas bem como o modo pelo qual as estórias que contavam iam sofrendo adaptações, modificações e regionalismos, insinua, ao hodierno historiador das práticas culturais, que o que essas mulheres empreendiam era uma apropriação daquelas canções, nos termos demarcados a este conceito/experiência histórica por Roger Chartier (2002) e Michel de Certeau (1999), conferindo a tais práticas um significado educativo. Tomando por base essa pista freyreana, lida à luz da contribuição dos historiadores franceses supracitados, minha hipótese é de que as amas apropriavam-se de representações nascidas de suas experiências pessoais ou que estavam em circulação e com as quais tomavam contato e, por meio de diferentes apropriações, tornavam práticas ligadas ao seu ofício - como contar estórias ou entoar canções de ninar ${ }^{3}$ - em práticas educativas, na medida em que visavam, com isso, incutir determinados hábitos e comportamentos aos nhonhôs e sinhás sob seus cuidados.

Sendo a História, como instiga a considerar Giovanni Levi, “[...] a ciência das perguntas gerais, mas das respostas locais" (LEVI, 2014, p. 1), o local a partir do qual procurarei ensaiar as primeiras respostas ao problema histórico aqui proposto é a cidade de Paranaguá, na Província do Paraná, entre os anos de 1870 e 1880 . A escolha por essa cidade deve-se, em parte, ao fato de integrar o território geográfico sobre o qual têm recaído minhas pesquisas ao longo dos últimos anos, mas, principalmente, porque, para essa região, encontrei fontes sobre essa presença feminina na história da educação e que, ao longo deste estudo, irei interrogar.

3 Em função dos limites deste artigo, tratarei somente das canções de ninar como práticas educativas. Contudo, optei por manter as estórias no enunciado da hipótese e nas reflexões desta introdução por dispor de evidências, aqui inexploradas, de que elas também integravam o repertório cultural dessas mulheres educadoras. 
Com efeito, como recuperar as vozes das amas escravas que cantavam melodias e contavam estórias aos pequenos filhos de seus senhores no século XIX? Delas, como da maioria das mulheres do passado, não chegaram até o historiador testemunhos diretos, produzidos em primeira pessoa. Até mesmo porque, pela maior parte, essas amas certamente não sabiam escrever, o que lhes impedia de registrar por escrito as suas impressões e ações. Todavia, seu aparente silêncio pode ser quebrado mediante a sensibilidade do historiador ou historiadora que toma a mulher como personagem central da cena histórica, uma vez que, como argumenta Michelle Perrot (2005), "é o olhar que faz a história" e um olhar sensível e sensibilizado aprende a capturar, senão as vozes das amas escravas, ao menos, os ecos de suas palavras na vida de alguns homens que, em adultos, registraram por escrito suas lembranças de uma infância vivida nos braços dessas mulheres por eles próprios ou por membros de suas famílias. É nesse sentido que a cidade de Paranaguá torna-se significativa, em termos empíricos, para esta investigação.

Em 1876, uma ama, a escrava Faustina, entrou na casa da importante família Correia, para ser ama de leite e depois ama-seca do pequeno Leocádio Cysneiros, nascido em fins de 1875 (doravante, Leocadinho, para diferenciá-lo de seu pai, portador do mesmo nome). Muitos anos depois, quando adulto e reconhecido literato no cenário paranaense, Leocadinho teve a oportunidade de escrever alguns relatos memorialísticos nos quais recorda sua infância e, dentro dela, a presença e atuação da sua "Mã Faustina", como carinhosamente designava sua "Mãe Preta". Além desse literato, um de seus descentes, Valério Hoerner Jr., detentor não só de memórias da família Correia transmitidas ao longo de três gerações, mas também de documentos a ela pertencentes, produziu um relato biográfico-memorialístico do pai de Leocadinho, o paranaense Leocádio Correia, aprofundando e desvelando novas questões relativas à presença e participação da ama Faustina na vida dessa família do século XIX. São esses textos memorialísticos a principal fonte para tentarmos ouvir, através de vozes masculinas, a voz e a ação de uma ama de leite na função de educadora de uma criança no Oitocentos.

Embora tais registros memorialísticos sejam escritos por homens, permitem ao historiador, em meio aos fios da memória e das retóricas da infância (BECCHI, 1994), aproximar-se dessas mulheres do passado, pelas imagens que delas oferecem. Diante dessa documentação, assumirei a mesma atitude de Georges Duby face às evidências que lhe permitiram vislumbrar as suas "Damas do Século XII", procurando "[...] mostrar reflexos, o que testemunhos escritos refletem" (DUBY, 2013, p. 10) do que foi a vida e as ações protagonizadas pelas amas escravas, mas conforme apreendidas por homens que, registrando por 
escrito memórias familiares que vivenciaram ou receberam, lançaram também sobre elas seu olhar.

No trabalho por desvelar tais reflexos, outras fontes também serão interrogadas (como jornais, fotografias e escritos do senhor de Faustina), bem como será estabelecido diálogo com a historiografia, visando auxiliar na crítica da documentação principal, uma vez que a memória - marca mais característica dessa empiria -, nos alerta Peter Burke (2000), serve tanto para lembrar quando para esquecer, produzindo seus sentidos de acordo com essas operações que presidem a sua produção. Operações que precisam ser consideradas e também questionadas pelo historiador ou historiadora da educação.

Dirijamo-nos, sem mais delongas, à Paranaguá dos anos 1870, para conhecermos a família Correia e sua ama Faustina...

\title{
Vestígios da história de uma escrava na história de uma família
}

Em dezembro de 1875, Leocádio Correia e sua esposa Carmela acompanharam o nascimento do primeiro dos seus três filhos (ao todo, seriam dois meninos e uma menina). Décadas mais tarde, Leocadinho, o primogênito, já homem feito, num relato em terceira pessoa, assim descreveu esse e os dias que a ele se seguiram:

\begin{abstract}
Natural da cidade de Paranaguá, nasceu, consoante assentamento da velha carteira paterna, no dia $1^{\circ}$ de dezembro de 1875 , as 8 horas menos 5 minutos da noite. Batizou-se na capela do Senhor Bom Jesus dos Perdões no dia 22 de janeiro de 1876, recebendo o nome - Leocádio - dos lábios do Padre Agostinho Machado Lima, vigário de Curitiba. Foram padrinhos o Comendador Manoel Antonio Guimarães, mais tarde Visconde de Nácar e sua avó materna D. Leocádia Pereira Lima. (CORREIA, 1923, p. 9).
\end{abstract}

Dos dados fornecidos pelo memorialista, evidencia-se ter ele vindo ao mundo numa família bem relacionada com a elite local, se recordarmos que os títulos nobiliárquicos eram concedidos primordialmente a homens abastados, como era o caso do seu padrinho (que cinco anos mais tarde daria abrigo ao Imperador quando em visita àquela cidade) e que era, também, o padrinho de seu pai. (HOERNER JR., 1979). Sabemos ainda que Leocádio, como observa 
o sociólogo Ricardo Costa de Oliveira, igualmente integrava a elite econômica e política do lugar, sendo "[...] do importante grupo familiar dos Correia do litoral [...] era abolicionista, foi vereador em Paranaguá e deputado provincial". (OLIVEIRA, 2001, p. 115). O clã dos Correias, era, ainda, de onde habitualmente saíam os líderes do Partido Conservador na Província.

No campo profissional, o pai de Leocadinho exercia a medicina, numa época em que os esculápios atuantes na Província podiam ser contados nos dedos de uma única mão. Apresentara, quando de sua formatura em 1874, uma tese sobre a cirurgia dos cálculos renais (HOERNER JR., 1979, p. 91), especializando-se posteriormente, pela prática do ofício, em assuntos ligados à epidemiologia. É interessante notar que enquanto muitos dos seus colegas da faculdade de Medicina do Rio, cujas teses foram estudadas por Karula (2012), se opunham à utilização de nutrizes - sobretudo escravas - para a alimentação dos recém-nascidos, Leocádio tenha seguido o que era hábito comum e corrente entre a maioria dos membros das classes abastadas do seu tempo: tratou de recorrer aos serviços de uma ama escrava.

Segundo narram as memórias familiares transmitidas por um dos seus descendentes, Valério Hoerner Jr., "[...] desde fins de 1875, porque o filho Leocadinho não tinha de sua mãe a quantidade de leite necessária, a escrava Faustina entrou na casa do Dr. Leocádio Correia, alugada de Maria Eufrásia de Amorim por dezoito mil réis mensais." (HOERNER JR., 1979, p. 79). Convém observar o modo como as memórias explicam a chegada de Faustina à residência dos Correia. Ela não teria vindo porque a mãe do menino se recusasse a alimentá-lo (uma das razões pela qual a chamada "amamentação mercenária" era alvo de crítica da classe médica), mas porque não tinha leite em quantidade suficiente para seu primogênito. Ao que parece, não havia na casa escravas que recém tivessem dado à luz, de modo que o recurso foi recorrer ao aluguel. Procurando em jornais paranaenses impressos nos meses de dezembro de 1875 e janeiro de 1876, não localizei nenhum anúncio pedindo o serviço de uma ama (ao contrário do que observei em meses anteriores e posteriores) e que pudesse ser atribuído aos Correia, o que permite supor que a negociação para o aluguel da ama Faustina tenha sido feita pessoalmente entre Leocádio e Maria Eufrásia Amorim.

E quem era a escrava Faustina, sobre quem recaiu a escolha e a negociação dos ricos brancos, afoitos por alguém que alimentasse um de seus pequenos? Dela, chegou até nós um retrato, tirado muito provavelmente entre 1876-1877. Trata-se, até onde a historiografia paranaense permite inferir, de imagem rara e inédita, o único retrato que chegou até nós de uma escrava que tenha vivido nesta região. 
FIGURA 1 -AAMA FAUSTINA E O PEQUENO LEOCADINHO (1876-1877)

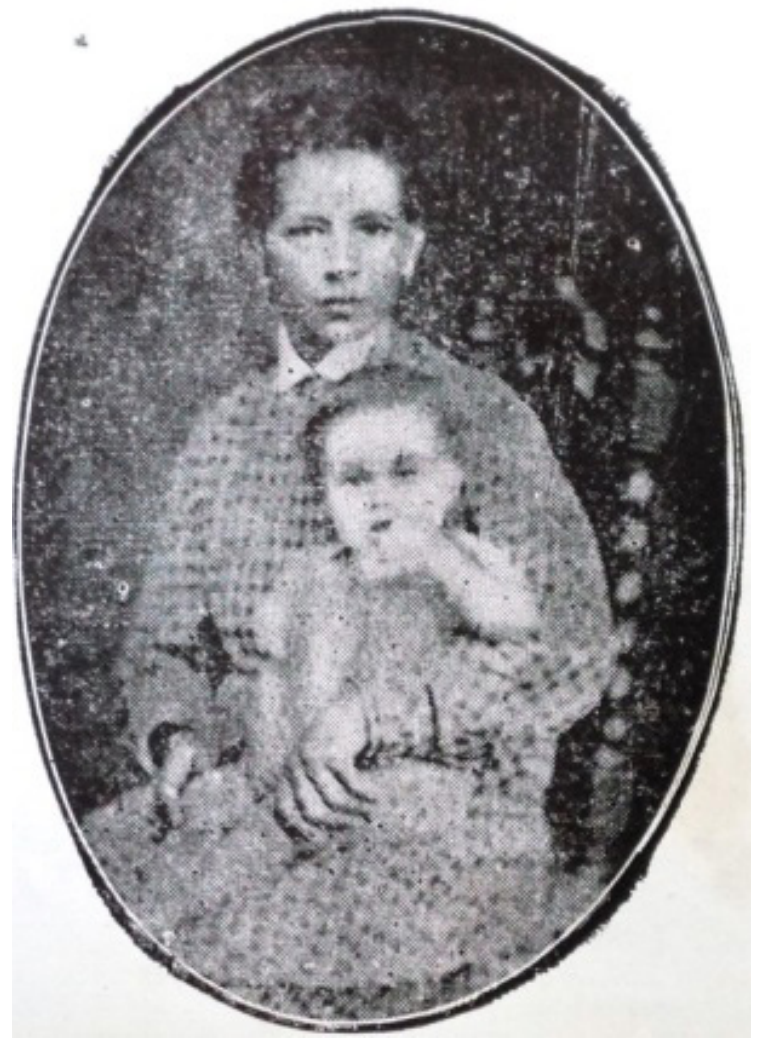

FONTE: CORREIA (1929).

De Faustina, Hoerner Júnior nos dá uma lacunar descrição: “Tinha 25 anos e o interessante é que, embora escrava, era de cor branca". (HOERNER JR., 1979, p. 76). Como apontou Hebe Mattos (2013), a construção da cor era um processo social bastante complexo ao longo do século XIX. No caso de Faustina, por mais "branca" que fosse considerada pela família Correia, sua fotografia nos revela ser ela mulata, possivelmente filha de pai branco com mãe negra. Era relativamente jovem, embora relativamente jovens também fossem os pais de Leocadinho: Leocádio tinha à época 27 anos e Carmela 24. Para o retrato, seguiu-se a montagem convencional nesse gênero fotográfico: o pequeno no colo da ama e ela trazendo-o junto de si, num gesto de carinho e afeto - atitudes esperadas das amas no desempenho de sua função de nutriz. 
Sobre esse carinho, Valério Hoerner Jr. teceu considerações ao recolher as memórias familiares: “[...] seus carinhos para com o menino eram grandes e mesmo quando não mais o amamentava era a ama carinhosa que acompanhava seus passos". (HOERNER JR., 1979, p. 79). Tamanha foi a afeição do menino e da família pela ama, que se decidiu por sua compra e após delicado processo de negociação, conforme anotações feitas por Leocádio e transcritas por Hoerner Jr., sabemos que em 10 de fevereiro de 1877 foi adquirida para Leocadinho “[...] pela dedicação com que se prestou, por $1.400 \$ 000[\ldots]$ pertencendo como aqui declaro a esse meu filho". (CORREIA, 1877 apud HOERNER JR., 1979, p. 78).

Se, por um lado, as memórias dos Correia enaltecem o amor e o carinho mútuos entre a ama e o pequeno, elas silenciam sobre um fato óbvio, tornando ainda mais gritante a partir do momento em que ela foi efetivamente adquirida pela família. Se, em 1876, Faustina esteve em condições de ser alugada como ama de leite, é porque tinha um filho pequeno, certamente ingênuo (a lei de 28 de setembro de 1871 já estava em vigor) e que até a idade de oito anos não pertenceria a ela, mas à sua antiga senhora e, dos oito aos vinte e um anos, à antiga senhora ou ao Estado, conforme escolha que aquela fizesse, segundo facultava-lhe a Lei do Ventre Livre. Logo, para cuidar de Leocadinho, Faustina teve de afastar-se do filho e, quando foi comprada para o menino, não há nenhuma evidência que indique que aquele tenha deixado a tutela da antiga senhora e passado à do novo senhor da mãe. Situações como essa são bem conhecidas na historiografia (KOUTSOUKOS, 2009), mas ocultam a contradição da exigência de carinho para com o filho do senhor e a privação desse mesmo carinho ao filho da ama, levada a preteri-lo. Teria sido por viver situação como a aqui sugerida pelos indícios (e pela ausência deles) que, no retrato, Faustina, ainda que se conformando à pose dela esperada, olha com tanta firmeza e até mesmo certa altivez para a lente que imortalizava em uma imagem o ideal esperado dela como ama no Oitocentos?

Deixando de lado as lacunas e suposições que legitimamente se podem enunciar - já que, como ensinava Bloch (2009), em nosso ofício, onde calcular é impossível, impõe-se sugerir- a última notícia segura que temos da escrava Faustina é que, após nove anos de serviço como ama de leite e, depois, ama seca, foi alforriada pelo pai do seu "sinhozinho", conforme anotação feita por Leocádio em seus apontamentos pessoais: "Completando Leocadinho 9 anos a 1 de dezembro deste 1884 concede - alforria à Faustina". (CORREIA, 1877 apud HOERNER JR., 1979, p. 78). No quadro das memórias familiares, esta seria a prova cabal tanto do reconhecimento da família pelo amor e cuidados dedicados à Leocadinho quanto da ação abolicionista de Leocádio Correia.

Entrementes, um telegrama datado de 02 de dezembro daquele mesmo ano, narrando eventos da noite anterior (ou seja, o dia da libertação de Faus- 
tina) e publicado na Gazeta Paranaense de 05 de dezembro de 1884, nos dá conta do verdadeiro motivo dessa libertação e a de todos os demais escravos dos Correia: a comemoração pela vitória do Partido Conservador nas eleições gerais daquele ano... (Gazeta Paranaense, 02 dez. 1884). Assim, não foi pelo que fez pelo pequeno que Faustina alcançou a liberdade, mas, provavelmente, pela oportunidade de uma comemoração política. Contudo, as memórias familiares, amparadas nessa anotação pessoal do Dr. Leocádio Correia, trataram de produzir-lhe sentido diverso... Em todo caso, Faustina só recebeu a alforria após ter participado também da educação de Leocadinho, educação cujos vestígios passaremos a analisar a seguir.

\section{Vestígios da ação de uma escrava na história da educação da criança pela família}

Em 05 de dezembro de 1928, Leocadinho proferiu uma palestra em Paranaguá no intuito de dar início a uma campanha para a construção de um monumento dedicado à figura da "Mãe Preta" (a exemplo de mobilização congênere que à época acontecia noutras partes do Brasil). Sua fala interessa-nos menos pela campanha em si do que pelas reminiscências de sua infância - e quiçá da infância de seus ouvintes, muitos nascidos nas décadas de 1870 e 1880 do século anterior - nas quais delineia os modos como sua "Mã Faustina" e outras escravas educaram meninos e meninas paranaenses. Sua fala foi publicada em um pequeno livreto em 1929, trazendo a fotografia de Leocadinho e Faustina, analisada páginas atrás. Sobre a sua ama em particular, eis o que rememorou naquela noite:

A mãe preta é esse tipo de mulher que ainda conservo na retina de minha alma e chamava-se "Mã Faustina" e que neste passado já tão distante de minha infância formosa me aconchegou ao peito apojado ou embalou-me em seus braços ao som rítmico e suave das cantigas maternais, na toada carinhosa e doce da voz humana, olhando o Itiberê a deslizar mansamente. (CORREIA, 1929, p. 10).

É certo que aqui quem nos fala é o adulto e sua rememoração não é inocente nem descompromissada, já que seu discurso fora feito para um auditório 
que, reunido para dar início à construção de um monumento à "Mãe Preta", o constrange a direcionar suas lembranças para os mesmos aspectos nobres e positivos que motivavam todo aquele movimento pela exaltação do papel dos negros na construção na nação. Porém, é notável que ele consigne em sua fala a visão positiva e harmoniosa da relação de sua família com a escrava Faustina, tal qual décadas mais tarde, seu descendente, Valério Hoerner, também o faria. Harmonia que, já observamos, esconde as contradições da condição da mulher escrava separada dos filhos para ser "Mã" dos filhos de seu senhor.

Para além das brumas desse monumento de memória, Leocadinho descreve, porém, sensações e experiências de quem esteve, de fato, em íntimo contato com uma ama. Recorda a si e aos ouvintes o tipo de cuidados recebidos na infância, quando aquela, cumprindo o que dela esperava-se, o aninhava e aconchegava no peito. Mas, principalmente, lembra-se das canções por ela entoadas. Ora, como já sugeria Gilberto Freyre (2000) - por sinal, em trabalho publicado poucos anos após essa fala de Leocadinho, - eram essas canções um dos modos pelos quais as amas atuavam na educação das crianças sob seus cuidados. Para alegria do historiador, Leocadinho recordou um trecho de duas, conforme as ouviu na infância. Uma cantada para meninos - e possivelmente para ele próprio - e outra entoada para meninas - que ele pode ter ouvido Faustina, ou outra ama, cantar para sua irmã Clara Correia, nascida em fins da década de 1870 . No primeiro caso, recitou ele o trecho da canção que parece ter sido frequentemente entoada por sua e pelas demais amas aos meninos:

Tutu Marambaia

mais cá

Te manda matá! (CORREIA, 1929, p. 10).
Não venha

Que o pai do menino

Não é de hoje que pesquisadores se debruçam sobre canções e acalantos escravos. Muitos folcloristas (CASCUDO, 1983), sociólogos (FERNANDES, 1958), estudiosos das africanidades (GUERRA, 2010) e da literatura (MACHADO, 2012) já ensaiaram importantes interpretações. O tom das análises geralmente foca-se na tentativa de compreender e interpretar os seres sobrenaturais que essas canções evocam, observa Silvia Machado (2012). A pesquisadora demonstrou, porém, que nelas há também a evocação de situações da vida de pessoas reais - no caso dos acalantos escravos, os cativos com suas dores, valores e temores - de modo metafórico. Focando-se em elementos como as menções aos diferentes lugares de dormir, evidenciou haver ali evidências da desigualdade social entre crianças cativas e livres. Inspirado nessa operação, 
penso ser possível desvendar sentidos educativos se, como Machado, centrarmos nossas indagações na interpretação dos elementos reais e não dos sobrenaturais presentes nessas canções. Trata-se, todavia, de um ensaio interpretativo, limitado, em parte, pela natureza das fontes, mas também pelo tipo de operação que, nos limites deste texto, é possível arriscar para um tema bastante vasto e complexo.

Na canção recolhida pela memória de Leocádio, mãe Faustina murmurava na sua cantilena de acalanto a figura de algo amedrontador e mítico - o Tutu Marambaia - que nada pode contra o menino pelo fato deste contar com a proteção de alguém real e poderoso - seu pai - tão poderoso que podia mandar matar o bisonho personagem. Com base num dos tipos de representação educativa que encontrei em minhas pesquisas - a educação liberal, fortemente ancorada no poder patriarcal brasileiro, embora dissimulada sob um aparente liberalismo que, na verdade, pela busca da regulação da liberdade dos indivíduos através da vivência de direitos e deveres apenas acabava por legitimar o poder e a autoridade paternos sobre a família, seus membros e dependentes (ANJOS, 2015) - é que acredito que havia, nessa oposição entre "o que ameaça" e "o que mata quem ameaça", uma forma de educação, na qual a ama, por meio de uma canção, incutia e naturalizava aos ouvidos infantis aquilo que, por outras vias, a lei visava naturalizar: o fato da existência de um poder paterno capaz de proteger os filhos e sob o qual estes estariam seguros. Afinal, na cantilena, a simples existência desse poder já era aviso ao ser fantástico que ameaçava o sono do menino. Na ousadia desse ser de incomodar o pequeno, aquele que podia mais e sob o qual tanto ele quanto a ama estavam sujeitos é que salvaria e defenderia o filho.

É interessante notar que havia variações dessa canção, devidamente documentadas (CASCUDO, 1983; GUERRA, 2010), em que ora evocava-se a figura do pai que manda matar e ora da mãe que viria espantar o Tutu. De novo, o viés patriarcal espreita o berço infantil. Enquanto a mãe só iria "espantar", o pai, pleno de poder, é que poderia "matar" o Tutu abusado. É nessa segunda variação, conhecida e mencionada por Leocadinho, que penso residir o mais importante vestígio da apropriação que Faustina pode ter feito dessa relação, uma vez que em sua voz era o pai do menino - Leocádio Correia, o mesmo senhor potente e poderoso, social, econômica e politicamente e que, na gana de garantir junto de si a ama tão querida pelo filho não hesitava em comprá-la, mesmo que a separando de seu filho verdadeiro - quem mandava matar. Era, possivelmente, a experiência da relação dessa escrava com aquele senhor, somada às representações sobre a autoridade paterna em circulação, que informaram a apropriação educativa que pode ter feito desta prática, pela qual, desde o colo da ama, Leocadinho foi aprendendo a naturalizar o eixo central da sociedade em 
que estava sendo inserido: a crença e a submissão à figura paterna, por conta do poder de proteção que detinha nas mãos.

$\mathrm{Na}$ outra canção rememorada por nosso personagem, novos vestígios de uma provável educação empreendida pelas amas, dessa feita, dada às meninas:

Menina bonita

na cama

Da sua mucama. (CORREIA, 1929, p. 11).
Não dorme

Só dorme no braço

Essa quadrinha mencionada por Leocadinho pode ter sido entoada por Faustina. O mais provável, para mim, é que integrasse o repertório de amas como ela que, quando no cuidado de meninas, precisavam recorrer a canções diferentes daquelas voltadas aos meninos. Essa escolha que é, em última análise, também uma forma de apropriação da prática, insere-nos, sem dúvida, na problemática da construção das relações de gênero, onde as canções adequadas aos ouvidos dos "nhonhôs" podiam não sê-lo aos ouvidos das "iaiás", isso porque, através delas, se visava incutir comportamentos e condutas diferenciados, por conta das diferenças entre o que se concebia como o "ser menino" e o "ser menina" no período aqui analisado.

Esse acalanto também possuía interessantes variações. No século XIX, a menina ora dormia no regaço de Sant'Ana (FREYRE, 2000) ora debaixo da rama (MACHADO, 2012) e, na versão que teria sido ouvida pelas meninas e meninos como Leocadinho na infância, dormia no braço da sua mucama. Embora, como já assinalado por Machado (2012), o lugar de dormir nessas canções seja importante, vale observar aqui a relação que se estabelece entre a atitude de uma menina bonita e uma "menina feia". A primeira é aquela que não dorme onde quer, mas onde dizem que é melhor para ela. Não a cama - onde, como se sabe, muitos acidentes podiam ocorrer, levando à morte das pequenas, coisa de que as amas também eram acusadas no Oitocentos (KARULA, 2012) -, mas nos braços da mucama, onde seria devidamente alimentada e protegida.

Em princípio, a canção era duplamente educativa, já que lembrava à ama a melhor forma de amamentar ao mesmo tempo em que ia incutindo na menina - futura mãe - o espírito da obediência e, indiretamente, naturalizando a melhor forma de cuidar dos filhos que viria a receber, numa época em que, paulatinamente, o cerco contra as "amas mercenárias" ia se fechando e, cada vez mais, se esperaria das próprias mães esses primeiros cuidados com os pequenos. Mas, acima de tudo, o que a canção naturalizava era que, enquanto o sono do menino poderia vir pela evocação de um ser sobrenatural que poderia morrer 
pelas mãos do seu pai, o sono da menina deveria vir pela obediência às ordens de quem, por vontade de seus pais, naquele instante em particular, tinha sobre ela algum poder, a ama.

Como disse linhas atrás, não é possível saber se Faustina entoou essa canção para Clara, irmã de Leocadinho. Entrementes, esse tipo de comportamento da parte de meninas era coisa que Leocádio considerava adequado para o sexo feminino. Em visita à escola de meninas da cidade de Paranaguá, quando ocupava o cargo de inspetor das escolas do lugar, em 1885 - ano seguinte à alforria de Faustina -, registrou de próprio punho em livro de correspondências, pertencente ao acervo do Instituto Histórico de Paranaguá, que estava satisfeito com o que encontrara na cadeira feminina. Dentre os motivos de sua satisfação estava "[...] o respeito necessário, a delicadeza atenciosa e o comportamento exemplar" (CORREIA, 1885, p. 3), coisas que, quiçá, por via das canções, amas como Faustina também podem ter tentado produzir nas meninas que dormiam em seus regaços de amas.

\section{Considerações a modo de (in)conclusão}

Em relação ao objetivo deste trabalho, foi possível identificar, dentre as práticas de que lançavam mão as "mães pretas" na educação das crianças sobre seus cuidados, as canções de ninar envolvendo seres fantásticos e referindo-se, ainda que metaforicamente, a experiências concretas por elas vivenciadas e ao modo como dialogavam com diferentes representações sociais em circulação. Essa prática das canções de ninar, por sinal, tornava-se educativa - ao menos no caso aqui estudado - na medida em que traduziam e naturalizavam para a criança, desde a infância, as relações patriarcais e de gênero em que elas e as amas estavam inseridas na sociedade brasileira Oitocentista.

Para além disso, este trabalho apontou para a possibilidade dos registros memorialísticos - de infância e sobre a infância - como fonte potencial para a escrita da história de mulheres em suas relações com processos educativos pretéritos, como as amas escravas que, mesmo não tendo deixado registros de si, podem ser capturadas nesses testemunhos masculinos que as mencionam, descrevem e evocam.

Contudo, os dados aqui levantados devem ser encarados, sobretudo, como resultados provisórios e que necessitam, ainda, de ampliação e maior problematização. Das várias questões ainda a serem aprofundadas, destaco apenas uma e, talvez, a mais provocadora. Se, como visto aqui, as amas escravas educavam 
de acordo com representações em circulação, das quais se apropriavam, qual o motivo das críticas tão contundentes a elas dirigidas no período em tela? Seria o preconceito racial a verdadeira razão desse posicionamento negativo em relação a elas? Ou o tipo de educação aqui identificado, cuja apropriação mais ou menos dialogava com as expectativas patriarcais, era uma exceção e, de modo algum, a regra em matéria da educação dada pelas amas escravas às crianças? O aprofundamento empírico e historiográfico que os primeiros resultados desta pesquisa ainda reclamam é que nos ajudará a responder e interpretar melhor essas e outras questões. Afinal, como dizia Lucien Febvre (2009), o historiador não é aquele que sabe, mas, antes, aquele que procura saber para melhor compreender.

\section{REFERÊNCIAS}

ANJOS, J. J. T. Pais e filhos na Província do Paraná: uma história da educação da criança pela família. Tese (Doutorado em Educação) - Universidade Federal do Paraná, Curitiba, 2015.

BECCHI, E. Retórica de Infância. Perspectiva, Florianópolis, n. 22, p. 63-95, ago./ dez. 1994.

BLOCH, M. A apologia da História ou o Ofício do Historiador. Rio de Janeiro: Zahar, 2009.

BURKE, P. Variedades de História Cultural. Rio de Janeiro: Civilização Brasileira, 2000.

CASCUDO, L. C. Geografia dos mitos brasileiros. Belo Horizonte: Itatiaia, 1983.

CERTEAU, M. A Invenção do cotidiano. Petrópolis: Vozes, 1999.

CHARTIER, R. A história cultural entre práticas e representações. Lisboa: Difel, 2002.

CIVILETTI, M. V. P. O cuidado às crianças pequenas no Brasil Escravista. Cadernos de Pesquisa, São Paulo, v. 76, p. 31-40, fev. 1991.

DUBY, G. Damas do Século XII. São Paulo: Companhia das Letras, 2013.

FEBVRE, L. O problema da incredulidade no século XVI. São Paulo: Companhia das Letras, 2009.

FERNANDES, F. Contribuição ao estudo sociológico das cantigas de ninar. Revista Brasiliense, São Paulo, n. 16, mar./abr. 1958.

FREYRE, G. Casa Grande \& Senzala. Rio de Janeiro: Record, 2000.

GRAHAM, S. L. Proteção e obediência. São Paulo: Companhia das Letras, 1992. 
GUERRA, D. Acalantos afro-brasileiros. Revista África e Africanidades, n. 8, p. 1-5, fev. 2010.

KARULA, K. Perigosas amas de leite: aleitamento materno, ciência e escravidão em A Mãi de Família. História, Ciência, Saúde - Manguinhos, Rio de Janeiro, v. 19, p. 197-214, dez. 2012.

KOUTSOUKOS, S. S. M. "Amas mercenárias": o discurso dos doutores em medicina e os retratos de amas - Brasil, segunda metade do século XIX. História, ciência, saúde - Manguinhos, Rio de Janeiro, v. 16, p. 305-324, abr./jun. 2009.

LEVI, G. O trabalho do historiador: pesquisar, resumir, comunicar. Tempo, Rio de Janeiro, v. 20, p. 1-20, 2014.

MACHADO, S. A. P. Canção de ninar brasileira: aproximações. Tese (Doutorado em Teoria Literária e Literatura Comparada) - Universidade de São Paulo, São Paulo, 2012.

MATTOS, H. Das cores do silêncio. Campinas: Unicamp, 2013.

OLIVEIRA, R. C. O silêncio dos vencedores. Curitiba: Moinho do Verbo, 2001.

PERROT, M. As mulheres ou os silêncios da História. Bauru: EDUSC, 2005.

QUINTAS, G. Amas de leite e suas representações visuais: símbolos sócio-culturais e narrativos da vida privada no Nordeste patriarcal-escravocrata na imagem fotográfica. RBSE - Revista Brasileira de Sociologia da Emoção, v. 8, n. 22, p. 11-44, abr. 2009.

VASCONCELOS, M. C. C. A casa e seus mestres. Rio de Janeiro: Gryphos, 2005.

\section{Documentos consultados}

CORREIA, L. Inspetoria Paroquial das Escolas de Paranaguá. 1885-1886. Códice manuscrito.

CORREIA, L. Pelo meu caminho. Curitiba: [s. n.], 1923.

CORREIA, L. C. Pagina Minima. Curitiba: [s. n.], 1929.

GAZETA PARANAENSE. Curitiba, 02 dez. 1884.

HOERNER JR., V. A vida do Dr. Leocádio. Paranaguá: Prefeitura Municipal, 1979.

Texto recebido em 19 de novembro de 2015.

Texto aprovado em 04 de janeiro de 2016. 